\title{
Bagaimana Konsep Pemilihan Pemimpin dalam Perspektif Konstitusi Indonesia dan Islam
}

\section{How the Concept of Leader Selection in the Perspective of the Indonesian Constitution and Islam}

\author{
Abdul Rohman \\ Universitas Islam Bandung, Bandung, Jawa Barat, Indonesia \\ abe131185@gmail.com
}

\begin{abstract}
Abstrak
Pemimpin menempati posisi penting karena memegang kebijakan yang berkaitan dengan hajat hidup orang banyak. Penelitian ini bertujuan untuk membahas konsep pemilihan pemimpin dalam persfektif konstitusi Indonesia dan Islam. Penelitian ini merupakan penelitian yuridis normatif, dengan menggunakan pendekatan kualitatif. Data yang diperoleh dari studi pustaka dikumpulkan dan dianalisis guna mendapatkan gambaran yang paling mendekati kebenaran. Hasil penelitian ini diantaranya: (1) Semua warga negara Indonesia dijamin hak untuk memilih berdasarkan hati nuraninya oleh konstritusi, melalui pemilu yang berasaskan LUBER dan JURDIL; (2) Islam sangat menekankan pada pemeluk agamanya untuk memilih pemimpin dari kalangan muslim. Meskipun pendapat Al-Mawardi membolehkan memilih non muslim dengan syarat bukan pemimpin eksekutif, legislatif, dan yudikatif (pusat), namun al-Qur'an dan Hadits lebih menguatkan akan keharusan bagi setiap yang beragama Islam memilih pemimpinnya sesama-sama seakidah (muslim). Maka dapat disimpulkan bahwa terdapat perbedaan prinsipal pada konsep pemilihan pemimpin dalam perspektif konstitusi Indonesia dan Islam. Kata Kunci: Indonesia, Islam, Konstitusi, Pemilihan \& Pemimpin
\end{abstract}

\section{Abstract}

Leaders occupy an important position because they hold policies related to the lives of many people. This study aims to discuss the concept of choosing a leader in the perspective of the Indonesian constitution and Islam. This research is a normative juridical research, with a qualitative approach. The data obtained from the literature study were collected and analyzed in order to get a picture that was closest to the truth. The results of this study include: (1) All Indonesian citizens are guaranteed the right to vote based on their conscience by the constitution, through elections based on LUBER and JURDIL; (2) Islam places great emphasis on its religious adherents to elect leaders from among Muslims. Although Al-Mawardi's opinion allows choosing non-Muslims on the condition that they are not executive, legislative and judicative (central) leaders, the Al-Qur'an and Hadith further strengthen the obligation for every Muslim to choose their leader of the same faith (Muslim). So it concluded that there were principal differences in the concept of selecting 
leaders in the perspective of the Indonesian constitution and Islam. Keywords: Election, Leader, Constitution, Indonesia, Islam

\section{PENDAHULUAN}

Kurniawan mengemukakan pemimpin menempati posisi penting dalam Islam, karena pemimpin memegang kebijakan yang berkaitan dengan hajat hidup orang banyak mulai dari kesehatan, transportasi, tata kelola sumber daya alam, kesejahteraan, dan pelbagai kebijakan publik lainnya (Kurniawan, 2015). Badruddin alHamawi as-Syafi' I yang wafat di abad 8 Hijriah, ia menyatakan dengan jelas keharaman memilih pemimpin dan juga apparat dari kalangan kafir dan juga apparat dari kalangan kafir dzimi (As-Syafi'i, 1988). Sementara, di Indonesia sendiri masih ada para penganut agama Islam yang mendukung calon pemimpin non muslim. Salah satunya yaitu pada pada pemilihan kepada daerah (Pilkaga), atau lebih khusus lagi pemilihan Gubernur (Pilgub) DKI Jakarta 2017.

Sumanto

menyebutkan bahwa diantara Pilkada yang digelar di Idnonesia, Pilkada Jakarta yang paling banyak menyita perhatian publik tanah air maupun masyarakat internasional. Ramainya pilkada Jakarta bukan karena adanya kandidat non muslim yang maju sebagai kepala daerah. Ada banyak kandidat non muslim di luar Jakarta yang ikut bertarung dalam Pilkada (baik di tingkat provinsi maupun kabupaten), tetapi adem ayem, biasa-biasa saja tidak seheboh Jakarta. Pilkada Jakarta menjadi ramai sesungguhnya karena ada sekelompok elit politik, tokoh agama, dan pedagang besar yang bernafsu menguasai Jakarta dengan beragam motif dan kepentingan tentunya. Kelompok politik ingin mengontrol jalannya roda pemerintahan sesuai dengan selera mereka. Kaum pebisnis tentu saja ingin dagangan mereka lancer tidak ada yang menghambat jalannya perbisnisan.

Sementara sekelompok elit agama terutama elit muslim, ingin Jakarta menjadi kota yang menerapkan normanorma atau standar-standar keagamaan/keislaman sesuai yang mereka imajinasikan (Sumanto, 2017).

Menurut data Data Dinas Kependudukan dan Pencatatan Sipil Provinsi DKI Jakarta, jumlah penduduk muslim DKI Jakarta 
mencapai 8.339.988 atau sebesar 83 persen dari total populasi. Jauh diatas polpulasi warga Kristen, Katolik, Buddha, Konghucu, dan lainnya. Ahok mendapatkan dukungan dari kalangan NU yang tergabung dalam Relawan Nusantara (RelaNU) bentukan Nusron Wahid mantan ketua PP GP Ansor periode 2010-2015, juga menghadiri Maulid Nabi Muhammad SAW yang diselenggarakan oleh RelaNU (15/01/2017), di markas RelaNU, Patra Jasa, Jakarta Selatan (Hasan, 2017).

Berdasarkan

paparan tersebut, maka penulis tertarik untuk meneliti baik secara konsep konstitusi Indonesia, maupun persfektif Islam mengenai hak-hak seorang muslim di Indonesia memilih pemimpin.

\section{METODE PENELITIAN}

Penelitian ini merupakan penelitian normatif, dimana menggunakan sumber data berasal dari studi kepustakaan, seperti seperti buku-buku, jurnal, peraturan perundang-undangan, maupun artikel yang didapat pada internet. Metode penelitian dilakukan secara kualitatif, yaitu tradisi tertentu dalam ilmu pengetahuan sosial yang secara fundamental bergantung pada pengamatan pada manusia dalam kehasannya sendiri, dan berhubungan dengan orang-orang tersebut dalam bahasannya, dan dalam peristilahannya (Rahmat, 2009). Selanjutnya, dianalisis dan ditarik kesimpulan untuk mendapatkan jawaban yang paling mendekati kebenaran.

III. HASIL DAN PEMBAHASAN

A. Pemilihan Pemimpin Dalam Persfektif Konstitusi Indonesia

Indonesia adalah negara hukum, hal ini diatur pada Pasal 1 ayat (3) UUD 1945. Yang disebut dengan negara hukum ialah negara yang berdiri diatas hukum yang menjamin keadilan kepada warga negaranya. Hukum yang bertujuan mengatur tata tertib masyarakat. Melihat tujuan dari hukum tersebut, baik masyarakat maupun pemerintah (Rohman, 2020). Indonesia yang mengedepankan hukum, tentunya harus serius menjaga kesetabilan tatanan kehidupan bernegara (Rohman, 2020). Hal ini pula yang menjadi landasan terlaksananya pesta demokrasi secara demokratis di Indonesia.

Demokrasi adalah suatu pemerintahan tempat rakyat ikut 
serta memerintah, baik secara langsung (demokrasi langsung), maupun secara tidak langsung (demokrasi tidak langsung) yang terdapat dalam negara-negara modern (Kusnardi \& Ibrahim, 1988). Indonesia menganut sistem demokrasi tidak langsung, karena adanya lembaga perwakilan sebagai pemegang amanah rakyatnya (Rohman, 2020). Sehingga penting rakyat untuk memberikan hak suara pada Pemilu yang berasaskan LUBER dan JURDIL, sebagaimana dipaparkan berikut ini:

\section{Asas Langsung}

Langsung, artinya rakyat pemilih mempunyai hak untuk secara langsung memberikan suara sesuai dengan kehendak hati nuraninya tanpa perantara (Frenki, 2016). Asas ini mengandung makna bahwa setiap warga negara harus melakukan pemilihan terhadap calon wakil rakyatnya tanpa diwakilkan oleh siapapaun. Meskipun ada yang menawarkan diri untuk mewakilinya, petugas dalam pelaksanaan pesta demokrasi tidak akan memberikan kesempatan bagi pemberi jasa pemungutan suara tersebut. Hal ini bertujuan untuk indevendensi hak pilih terhadap subjek hukum yaitu warga negara tanpa adanya kecurangan dalam Pemilu.

2. Asas Umum

Umum, artinya semua warga negara yang telah berusia 17 Tahun atau telah menikah berhak untuk ikut memilih, dan telah berusia 21 tahun berhak dipilih dengan tanpa ada diskiriminasi (Frenki, 2016). Asas ini memberikan makna bahwa tidak ada seorangpun yang berhak untuk mencegah seseorang untuk melaksanakan haknya dalam memberikan suara, siapapun, dari kalangan apapun, bahkan pemilih pemula yang masih duduk dalam bangku sekolah, apabila yang bersangkutan telah berusia 17 tahun maka sudah berhak untuk memberikan hak suaranya pada pemilu. Selanjutnya, asas ini memberikan jaminan bagi siapapun untuk mencalonkan diri sebagai pemimpin dalam kompetisi demokrasi rakyat. Siapapun yang telah berusia 21 tahun berkah untuk ikut serta dalam pemerintahan, yaitu menjadi pemimpin atau wakil rakyat, sebagaimana jaminan konstitusi Indonesia, yaitu Pasal 27 ayat (1), yaitu "Segala warga negara bersamaan kedudukannya di dalam hukum dan pemerintahan, dan wajib menjunjung hukum dan pemerintahan dengan tidak ada 
kecualinya." Selanjutnya, asas umum ini diatur pada Pasal 28D ayat (1), yaitu "Setiap orang berhak atas pengakuan jaminan, perlindungan, dan kepastian hukum yang adil serta perlakuan yang sama di depan hukum." Kemudian, Pasal 28I ayat (2) menyebutkan juga bahwa "Setiap orang berhak atas perlakuan yang bersifat diskriminatif atas dasar apapun, dan berhak mendapatkan perlindungan terhadap perlakuan yang bersifat diskriminatif." Bunyi pasal tersebut dapat dijadikan dasar bagi siapapun yang diperkalukan diskriminatif oleh panitia Pemilu. Contohnya, tidak mendapatkan surat undangan untuk memberikan suara, tidak diberikan pelayanan informasi data kepemilihan, serta perlakuan yang tidak adil saat mengantri di tempat pemungitan suara (TPS). Berdasarkan konstitusi Indonesia, tidak mengenal status sosial antara si kaya dan si miskin ataupun pejabat dan rakyat biasa, semua warga negara diperlakukan sama dan dijamin oleh konstitusi secara tegas.

3. Asas Bebas

Bebas, artinya rakyat pemilih berhak memillih menurut hati nuraninya tanpa adanya pengaruh, tekanan atau paksaan dari siapapun/dengan apapun (Frenki, 2016). Berbicara mengenai asas ini, sangat berhubungan sekali dengan topik yang dibahas pada penelitian ini. Asas bebas ini dihubungkan dengan Pasal 28I ayat (2) bahwa "Setiap orang berhak atas perlakuan yang bersifat diskriminatif atas dasar apapun, dan berhak mendapatkan perlindungan terhadap perlakuan yang bersifat diskriminatif". Selanjutnya, dihubungkan pada Pasal 28G ayat (1), yaitu "Setiap orang berhak atas perlindungan pribadi, keluarga, kehoormatan, martabat, dan harta benda yang di bawah kekuasaannya, serta berhak atas rasa aman dan perlindungan dari ancaman ketakutan untuk berbuat atau tidak berbuat sesuatu yang merupakan hak asasi." Kedua pasal tersebut sudah mencakut pada jaminan terhadap kebebasan bagi warga negara memilih siapapun dalam pemilu, sebagaimana asas bebas ini. Sehingga, apabila ada siapapun yang menodai kebebasan dalam memilih pada warga negara Indonesia, maka telah melanggar konstitusi negara kita.

Ketentuan di atas, apabila dihubungkan pada kasus yang dipaparkan sebelumnya, maka 
sepatutnya isu-isu keagamaan, apalagi berhubungan dengan agama yang dipeluk mayoritas rakyat di Indonesia (Islam), tidak menjadi media jualan politiknya elit-elit tertentu, karena dalam konstitusi negara Indonesia jelas bahwa adanya jaminan kebebasan bagi seluruh rakyat Indonesia menentukan pilihannya.

\section{Asas Rahasia}

Rahasia artinya rakyat pemilih dijamin oleh peraturan tidak akan diketahui oleh pihak siapapun dan dengan jalan apapun, siapa yang dipulihnya atau kepada siapa suaranya diberikan "Scret Ballot" (Frenki, 2016). Asas ini merupakan jaminan terhadap warga negara mengenai kerahasiaan pemberian suara pada pemilu. Pada teknis pelaksanaan Pemilu berdasarkan asas ini, pemerintah perlu menyiapkan logistik yang sebaik mungkin, guna mengantisipasi adanya kecurangan dalam Pemilu. Dasar atauran yang dipergunakan sama seperti pada asas bebas, yaitu jaminan terhadap hak pribadi terhadap ancaman maupun kewajiban penghormatan bagi warga negara lainnya, guna terciptanya pemilu berdasarkan asas rahasia, sebagaimana jaminan tersebut ditegaskan melalui Pasal
28J ayat (1) UUD 1945, "Setiap orang wajib menghormati hak asasi manusia orang lain dalam tertib kehidupan bermasyarakat, berbangsa dan bernegara."

5. Asas Jujur

Jujur artinya dalam penyelenggaraan pemilu, penyelenggaraan pelaksana, pemerintah dan partai politik peserta pemilu, pemantau pemilu, termasuk pemilih, serta semua pihak yang terlibat secara tidak langsung, harus bersikap jujur sesuai dengan peraturan perundang-undangan (Frenki, 2016). Dalam asas ini memang sulit untuk dikawal hanya berdasarkan pengamatan, penting pembinaan serta kegiatan pengawalan secara ketat terhadap pelaksanaan Pemilu. 6. Asas Adil

Adil, dalam penyelenggaraan Pemilu setiap pemilihan dan partai politik peserta Pemilu mendapat perlakuan yang sama dan bebas dari kecurangan pihak manapun (Frenki, 2016). Perlakuan yang sama yang menjadi asas pemilu ini, sebagaimana dalam Pasal 28 UUD 1945, yaitu "Kemerdekaan berserikat dan berkumpul, mengeluarkan pikiran dengan lisan dan tulisan dan sebagainya ditetapkan denga undang- 
undang." Selanjutnya, Pasal 28C ayat (2) UUD 1945 yang berbunyi: "Setiap orang berhak memajukan dirinya dalam memperjuangkan haknya secara kolektif untuk membangun masyarakat, bangsa dan negaranya." Paparan tersebut menjelaskan bahwa berpolitik dalam partai yang menjadi wadah bagi para warga negara memiliki hak dalam memperjuangkan kemenangan secara sportif. Selanjutnya, Pasal 28I ayat (5) menjelaskan bahwa "Untuk menegakan dan melindungi hak asasi manusia sesuai dengan prinsip negara hukum yang demokratis, maka pelaksanaan hak asasi manusia dijamin, diatur, dan dituangkan dalam peraturan perundang-undangan."

Berdasarkan paparan tersebut, peran pemerintah sangat dominan sekali untuk menciptakan Pemilu yang demokratis. Sehingga, asas adil ini dapat dilaksanakan secara optimal baik bagi partai politik maupun pihak-pihak yang kepentingan pada pesta demokrasi tersebut. Disinilah penting kehadiran negara sebagai lembaga yang mengedepankan tata pemerintahan berdasarkan sila kelima pancasila, yaitu "Keadilan sosial bagi seluruh rakyat Indonesia."

Pasal 28 J ayat (2) berbunyi "Dalam menjalankan hak dan kebebasannya, setiap orang wajib tunduk kepada pembatasan yang ditetapkan dengan undang-undang dengan maksud semata-mata untuk menjamin pengakuan serta penghormatan atas hak kebebasan orang lain dan untuk memenuhi tuntutan yang adil sesuai dengan pertimbangan moral, nilai-nilai agama, keamanan, dan ketertiban umum dalam suatu masyarakat demokratis," al-Chaedar dalam bukunya yang berjudul "Reformasi Prematur (Jawaban Islam Terhadap Reformasi Total)", menyebutkan bahwa bangsa Indonesia harus lebih serius melakukan reformasi di bidang politik, yang menjadi dasar di bidang lain, seperti ekonomi, hukum, sosial, pendidikan, dan yang lainnya (Rohman, 2020). Sehubungan dengan paparan tersebut, maka dapat disimpulkan bahwa warga muslim maupun non muslim, berdasarkan konstitusi Indonesia dijamin haknya. Seseorang mau memilih dari kalangan seagama ataupun tidak, negara selalu menjamin atas kebebasan serta kerahasiaan pilihan warganya. 


\section{B. Pemilihan Pemimpin dalam Persfektif Islam}

Pemimpin adalah orang yang wajib tunduk dan patuh kepada perintahnya semasa ia menjadi kepala atau ketua dari suatu Lembaga yang dipimpinnya (Nawawi, 1993). Mekanisme pemilihan atau pengangkatan pemimpin dalam Islam, terutama pada sejarah awal perpolitikan berbeda-beda polanya (R. Toni, 2015). Seperti halnya Rassulullah menjadi pemimpin melalui kesepakan yang alami (R. Toni, 2015). Hal ini berbeda pada masa wafatnya Rassulullah, yaitu pada masa Khulafa Al Rasyidin, Bani Umayyah dan Bani Abbasiyah (R. Toni, 2015). Pada masa ini mekanisme atau pengangkatan pemimpin dilakukan melalui beberapa cara (R. Toni, 2015):

1. Pada masa Abu Bakar, pengangkatan sebagai khalifah (pemimpin) dilakukan melalui mekanisme pengangkatan langsung aklamasi) dan pembi'atan, dengan berlandaskan kesepakatan akan keutamaan beliau.

2. Pada masa Umar Bin Khatab, pengangkatan sebagai khalifah (pemimpin) dulakukan melalui mekanisme pemberian wasiat oleh Abu Bakar r.a, tetapi terlebih dahulu dilakukan pertimbangan dan musyawarah akan calon khalifah yang akan diberikan wasiat. (al-muwardi memberikan syarat dalam proses pengangkatan dengan cara wasiat, yaitu dengan adanya kerelaan hari bagi sang penerima wasiat).

3. Pada masa Utsman bin Affan, pemilihan khalifah (pemimpin) melalui musyawarah melalui mekanisme pemilihan oleh Majelis Perwakilan atau Dewan Perwakilan yang terdiri dari 6 (enam) anggota yang ditetapkan oleh khalifah Umar, yang memilih calon khalifah.(pemimpin) dilakukan melalui mekanisme pembai'atan karena revolusi (pemberontakan bersenjata), hal ini dilakukan jika telah memenuhi syaratsyarat tertentu. Cara ini tidak bisa dilegalkan jika kepala negara masih dalam statusnya sebagai orang muslim. Karena waktu itu status memang tidak adanya seorang pemimpin, konsekuensinya adalah prosses pengangkatan pemimpin melalui ba'iat, maka fokus musyawarahlah pada kepentingan masyarakat, tidak 
pada kepentingan calon pemimpinnya, untuk mengisi kekosongan kepemimpinan.

4. Sedangkan pada masa Bani Umayyah dan Bani Abbasiyah, pengangkatan sebagai khalifah (pemimpinan) dilakukan melalui mekanisme peralihan kekuasaan, Mawiyah bin Abu Sufyan menjadi khalifah menggantikan Ali bin Abi Thalib melalui perebutan kekuasaan. Sedangkan Yazid bin Muawiyah, suksesi kepemimpinan terjadi melalui pewarisan kepada anak atau kerabat seperti lazimnya sistem monarki. Suatu sistem suksesi kepemimpinan yang sejatinya tidak sejalan dengan identitas Islam. Pada masa pemerintahan tersebut, system demokrasi Islam mengalami pergantian menjadi sistem monarkis (kerajaan).

Melihat paparan di atas, yang mirip dengan demokrasi Indonesia adalah masa khalifah Utsman bin Affan, karena dalam institusi terdapat lembaga perwakilan rakyat, yaitu Majelis Perwakilan dan Dewan Perwakilan. Selain itu, penentuan pemimpin lebih demokratis karena adanya musyawarah, yang diidentikan dengan demokrasi dalam Pemilu secara demokratis di Indonesia. Untuk memberikan pencerahan terhadap pandangan Islam bagi seorang muslim memilih pemimpin, maka penulis memberikan beberapa kajian.

Dalam kepemimpinan Islam, setelah 23 tahun berjuang dan berusaha dijalan keimanan Islam, dan dalam upaya membangun masyarakat madani, Nabi SAW pun wafat di awal tahun ke-11 Hijriah. Dengan wafatnya jiwa yang agung ini, wahyu al-Qur'an dan siklus kenabianpun berakhir. Tidak ada lagi nabi yang akan muncul, juga tidak akan ada lagi dispensasi agama berikutnya. Namun, tanggung jawab yang diemban nabi (terlepas dari tanggung jawab yang berkenaan dengan penyampaian wahyu), tentu saja tidak berakhir. Jelas penting, selepas wafatnya, agar setiap orang yang tercerahkan dan jujur, memikil tanggung jawab ini, sebagai pengganti dan wakil. Sekaligus imam dan pemimpin kaum muslim (Arkanudin, 2018).

Keyakinan agama sebagai pedoman dan sendi dasar kehidupan bermasyarakat yang paling utama dan paling mampu membangkitkan semangat 
membangun dan melestarikan alam. Adapun fungsi agama adalah sebagai kekuatan moral yang dapat mengendalikan keinginan hawa nafsu manusia (Diana dkk, 2018), Islam merupakan agama dan risalah yang mengandung asas-asas yang mengatur ibadah, akhlak dan muamalat manusia (Iriany, 2017). Ada beberapa dasar kepemimpinan dalam Islam yang harus dijadikan landasaran berorganisasi, diantaranya:

1. Tidak mengambil orang kafir atau orang yang tidak beriman sebagai pemimpin bagi orangorang muslim karena bagaimanapun akan mempengaruhi terhadap kualitas keberagamaan rakyat yang dipimpinnya. Sebagaimana firman Allah SWT dalam AlQur'an surat an-Nisa ayat 144, yang berbunyi: "Hai orangorang yang beriman, janganlah kamu mengambil orang-orang kafir menjadi wali dengan meninggalkan orang-orang mukmin. Ingainkah kamu mengadakan alasan yang nyata bagi Allah (untuk menyiksamu)" (http//repository.unsu.ac.id, diakses pada 21 Desember 2020).
2. Tidak mengangkat pemimpin dari orang-orang yang mempermainkan agama. Sebagaimana firman Allah SWT dalam Qs al-Maidah ayat 57, yang berbunyi: "Hai orangorang yang beriman, janganlah kamu mengambil jadi pemimpinmu, orang-orang yang membuat agamamu jadi ejekan dan permainan, (yaitu) diantara yang telah diberi kitab sebelummu, dan orang-orang yang kafir (orang-orang musyrik). dan bertakwahlah kepada Allah jika kamu betulbetul orang-orang yang beriman,"

(http//repository.unsu.ac.id, diakses pada 21 Desember 2020).

3. Pemimpin harus mempunyai keahlian di bidangnya, pemberian tugas atau wewenang kepada yang tidak berkompeten akan mengakibatkan rusaknya pekerjaan, bahkan organisasi yang menaunginya. Sebagaimana sabda Rassulullah SAW. Artinya: "Apabila disertakan kepada yang bukan ahlinya maka tunggulah masa kehancurannya." (H.R. Bukhari Muslim). (http//repository.unsu.ac.id, 
diakses pada 21 Desember 2020).

4. Pemimpin harus bisa diterima (acceptable), mencintai dan dicintai umatnya, mendoakan dan didoakan oleh umatnya (http//repository.unsu.ac.id, diakses pada 21 Desember 2020). Sebagaimana sabda Rossulullah SAW: "Sebaikbaiknya pemimpin adalah mereka yang kamu cintai dan mencintai kamu, kamu berdoa untuk mereka dan mereka berdoa untuk kamu, seburukburuknya pemimpin adalah yang kamu benci dan mereka yang membenci kamu, kalau melaknati mereka dan mereka melaknati kamu." (H.R. Muslim). (Rahmat, 2000).

5. Pemimpin harus mengutamakan, membela dan mendahulukan kepentingan umat, menegakan keadilan, melaksanakan syariat, berjuang menghilangkan segala bentuk kemungkaran, kekufuran, kekacauan, dan fitnah. Sebagaimana firman Allah SWT dalam Al-Qur'an Qs al-Maidah ayat 8 yang artinya: "Hai orangorang yang beriman hendaklah kamu jadi orang-orang yang selalu menegakan (kebenaran) karena Allah, menjadi saksi dengan adil. dan janganlah sekali-kali kebencian terhadap sesuatu kaum, mendorong kamu untuk berlaku tidak adil. Berlaku adillah, karena adil itu lebih dekat kepada takwa. dan bertakwalah kepada Allah, sesungguhnya Allah maha mengetahui apa yang kamu kerjakan." (http//repository.unsu.ac.id, diakses pada 21 Desember 2020).

Masyarakat yang melupakan nilai ajaran-ajaran agamanya, cenderung berperilaku melalaikan norma (Rohman, 2020). Melihat paparan di atas, maka Islam dengan tegas menyatakan bahwa memilih pemimpin itu harus dari kalangan muslim. Dalam Kitab Bahtsul Masail (2015) dipaparkan beberapa pandangan ulama terkait topik tersebut, diantaranya:

1. Badruddin al-Hamawi as-Syafi' $i$ yang wafat diabad 8 Hijriah, ia menyatakan dengan jelas keharaman memilih pemimpin dan juga apparat dari kalangan kafir dzimmi. "Tidak boleh mengangkat dzimi untuk jabatan apapun yang mengatur umat Islam kecuali untuk memungut upeti penduduk kalangan 
dzimmi atau untuk memungut pajak transaksi jual-beli penduduk kalangan musyrikin." Sedangkan untuk memungut upeti, pajak sepersepuluh, atau retribusi lainnya dari penduduk muslim, tidak boleh mengangkat mereka untuk jabatan apapun yang menangani kepentingan umum umat Islam. Allah berfirman, "Allah takkan pernah menjadikan jalan bagi orang kafir untuk mengatasi orang-orang beriman." Siapa yang mengangkat dzimmi sebagai pejabat yang menangani hajat muslim, maka sesungguhnya ia telah memberikan jalan bagi dzimmi untuk menguasai muslim (Lihat Baharuddin al-Hamawi asSyafi'I, "Tahrirul Ahkam fi Tadbiri Ahlil Islam," Qatar: Daruts Tsaqafah, 1988). Melihat paparan tersebut, dapat ditarik kesimpulan bahwa seseorang yang beragama Islam sangat tegas dilarang untuk memilih pemimpin dari kalangan non muslim.

2. Al-Mawardi, yang juga bermadzhab Syafi'i. Ulama yang wafat pada pertengahan abad 5 Hujiah ini memberikan tafshil, rincian terhadap jabatan, diantaranya: "Posisi pejabat ini (tanfidz/eksekutif) boleh diisi oleh dzimmi (non muslim yang siap hidup bersama muslim). Namum, untuk posisi pejabat tafwidh (pejabat dengan otoritas regulasi, legislasi, yudikasi, dan otoritaslainnya), tidak boleh diisi oleh kalangan mereka," (Lihat AlMawardi,"Al-Ahkamus

Sulthoniyah wal Wilayatud Diniyah," Beirut: Daril Fikr, Cetakan ke-1, hlm. 27). Melihat paparan tersebut, dapat diartikan bahwa selama bukanlah jawabatan-jabatan yang berhubungan dengan regulasi peradilan, serta eksekutif (pusat), maka non muslim boleh dipilih oleh seseorang yang beragama Islam. Namun selanjutnya Al-Mawardi mensyaratkan untuk pemimpin tersebut harus memiliki pemahaman akan hukum agama secara keseluruhan.

Berdasarkan paparan di atas, baik menurut al-Qur'an, Sunnah Nabi SAW, maupun pendapat ulama, untuk para kaum muslimin lebih ditekankan untuk memilih pemimpin dari kalangan muslim juga. Tentu saja hal ini dikarenakan beratnya menentukan seseorang 
yang non muslim tersebut benarbenar memahami agama secara universal atau tidaknya. Sementari al-Qur'an dan Hadits yang menjadi sumber hukum utama lebih condong pada keutamaan seorang pemimpin dikalangan muslim sendiri. Kendatipun demikian, secara konstitusi Indonesia tetap dijamin kebebasan serta kerahasiaan seorang muslim dalam memilih pemimpinnya berdasarkan hati nuraninya sendiri, tanpa adanya diskriminasi maupun ancaman dari semua pihak, termasuk dari golongan muslim sendiri.

\section{KESIMPULAN}

Berdasarkan hasil penelitian dapat disimpulkan bahwa terdapat perbedaan prinsipal pada konsep pemilihan pemimpin dalam perspektif konstitusi Indonesia dan Islam.

\section{DAFTAR PUSTAKA}

Arkanudin. A. (2018). Telaah Konsep Kepemimpinan Literatur Islam dan Indonesia. Al Qodri: Jurnal Pendidikan, Sosial dan Keagamaan, 15 (2), 14-31.

As-Syafi'i, Badruddin Al-Hamawi. (1988). Tahrirul Ahkam fi Tadbiri Ahlil Islam. Qatar: Daruts Tsaqafah

Diana, Rashda., Masruri, Siswanto \& Surwandono, Surwandono. (2018). Etika Politik dalam Persfektif al-Mawardi. TSAQAFAH: Jurnal Peradaban Islam, 14 (2), hlm, 363-384.

Frenki. (2016). Asas-Asas Dalam Pelaksanaan Pemilihan Umum Indonesia Menurut Fiqh Siasyah. ASAS: Jurnal Hukum Ekonomi Syari'ah, 8 (1), 54-65.

Hasan, Akhmad Muawal. (2017). Kuatnya Sentimen Agama di Pilgub Jakarta.

Diakses pada 19 Desember 2020, dari https://tirto.id/kuatnyasentimen-agama-di-pilgub-jakarta-ciZn.

Iriany, Ieke Sartika. (2017). Islam dan Demokrasi. Jurnal Komunikasi: Hasil Pemikiran dan Penelitian, 3 (1), 28-44.

Kusnardi, Mohammad \& Ibrahim, Harmaily. (1988). Pengantar Hukum Tata Negara Indonesia, cetakan ke-7. Jakarta: PD. Budi Chaniago.

Kurniawan, Alhafiz. (2015). Memilih Pemimpin Non Muslim, Bolehkah?. Diakses $\quad$ pada $19 \quad$ Desember 2020 dari 


\section{https://islam.nu.or.id/post/read/63567/memilih-pemimpin-non- muslim-bolehkah.}

Nawawi, Hadari. (1993). Kepemimpinan Menurut Islam. Yogyakarta: Gajahmada University Press.

R Tony, Prayogo. (2015). Konsep Pemilihan Kepala Daerah di Indonesia dalam Persfektif Islam. Jurnal Legislasi Indonesia, 12 (1), 1-34.

Rahmat, Pupu Saeful. (2009). Penelitian Kualitatif. EQIULIBRIUM, 5 (9), 1 8.

Rohman. Abdul. (2020). Sisi Positif dan Negatif Demonstrasi Pada Negara Demokrasi Dimasa Pandemi. Jurnal Ilmu Hukum: Binamulia Hukum, 9 (2), 153-170.

Rohman. Abdul. (2020). (2020). Kewenangan Penjabat Kepala Desa Dalam Mengangkat Kepala Desa. Syiar Hukum: Jurnal Ilmu Hukum, 18 (1), 62-82.

Rohman. Abdul. (2020). Implementasi Perlindungan Hukum Jurnalis Dalam Menjalankan Profesinya Berdasarkan Undang-Undang Nomor 40 Tahun 1999 Tentang Pers. Aktualita: Jurnal Ilmu Hukum, 3 (1), 58-80.

Rohman, Abdul \& Huda, N. (2020). Dampak Penanaman Nilai-Nilai Pancasila Terhadap Semangat Kebangsaan Pada Siswa SMK Bani Mahfud. CIVITAS: Jurnal Pembelajaran dan Ilmu Civic, 2 (1), 20-30.

Rohman, Abdul. (2020). Politik Birokrasi Pengangkatan dan Pemberhentian Perangkat Desa Pasca Pilkades. IGJ: Kajian Politik-Pemerintahan, 3 (2), 127-138.

Sumanto, al-Qurtubi. (2017). Arus Cina-Islam-Jawa: peranan Tionghoa dalam penyebaran Islam di Nusantara abad 15 \& 16. Lembaga Studi Sosial dan Agama (eLSA) 